\title{
低ひずみ速度試験中に発生・進展する応力腐食割れの 直接観察およびその破壊力学的統計的評価
}

\author{
柴田俊夫*, 春名 匠* \\ * 大阪大学工学部材料開発工学科
}

\author{
In-situ Observation of Stress Corrosion Crack during Slow Strain \\ Rate Test and Estimation of the Crack Behavior \\ by Fracture Mechanics and Statistics \\ Toshio Shibata* and Takumi Haruna* \\ * Department of Materials Science and Processing, \\ Faculty of Engineering, Osaka University
}

\begin{abstract}
Slow strain rate test, SSRT, has been widely used for studies of stress corrosion cracking, SCC. In evaluating SCC susceptibility, it is important to analyze initiation and growth of SCC separately even if SSRT is used. Then we have developed a new SSRT system with a high magnification and high focusing depth CCD camera in order to make in-situ observation of crack behavior on the whole specimen surface during SSRT, and analyzed initiation and growth of crack separately by using fracture mechanics and statistics. As a result, the number of pits, at which crack generated, was found to increase with increase in strain. The Weibull distribution was found for $K_{\mathrm{Iscc}}$ and its mode was $2 \mathrm{MN} \cdot \mathrm{m}^{-3 \cdot 2}$. While, crack growth rate showed double exponential distribution and its mode was about $10^{-8} \mathrm{~m} \cdot \mathrm{s}^{-1}$. Thus, This technique could evaluate SCC susceptibility by separating crack initiation and growth.
\end{abstract}

Key words: stress corrosion cracking, slow strain rate test, in-situ observation of crack behavior, $K_{\text {ISCC }}$, crack growth rate

1. 緒言

近年, 応力腐食割れ (SCC) 試験法の一つである低ひ ずみ速度試験 (Slow Strain Rate Technique: SSRT)

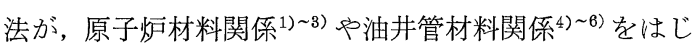
めとして, SCC 研究に広く用いられるよらになった。

この SSRT による SCC 感受性の評価は, 一般的に 試験後の SCC 破面率, 破断伸び, 最大応力やそれらを 組又合わせたパラメーターなどの因子により，比較的単 純に行われている。しかしながら，これらの因子には， き裂の発生・進展過程が複雑に影響を及ぼすことが考え られるため, SCC 現象をさらに詳細に検討するために はき裂の発生・進展過程を区別してそれぞれを評価する 必要がある。き裂の挙動に注目した SCC 感受性の評価 には, 従来, WOL 試験片や DCB 試験片など単一予き

* 干565 大阪府吹田市山田丘 2-1 (2-1, Yamada-oka, Suita, Osaka, 565 Japan)
裂を有する試験片を用いた破壊力学的試験が行われてお $\eta^{7)}$ ９), き裂長さの光学顕微鏡による直接測定, 電気抵抗 測定などによる間接測定によって, SCC 発生の臨界応 力拡大係数 $\left(K_{\mathrm{ISCC}}\right)$ やき裂進展速度など SCC に関して 重要な情報が得られている。しかし, これらの試験片の 加工コストが高いこと, また $K_{\mathrm{ISCC}}$ に近い力学的条件で は, き裂進展の開始むでに長時間を必要とする場合があ ることなどの欠点がある。

そこで本研究では, SSRT 中に平滑試験片上に発生す る多数個のき裂の発生・進展過程を CCD カメラを用い て連続的に観察するシステムを試作し, 試料表面上の個 々のき裂挙動（数, 発生時間, 破壊力学的因子など）を 解析し, 統計的に検討することを試みた。

\section{2. 実験装置}

Fig. 1 に実際に本研究で用いた CCD カメラ付 SSRT 


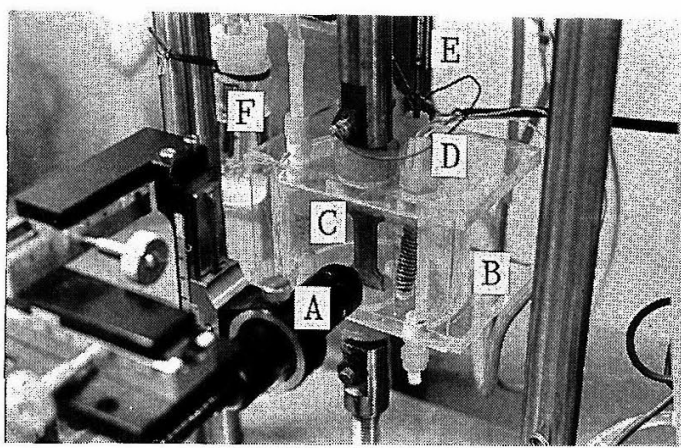

Fig. 1 A cell of the slow strain rate test attached with CCD camera system.

A: CCD camera, B: Cell, C: Specimen, D: Heater, E: Thermocouple, F: Reference electrode.

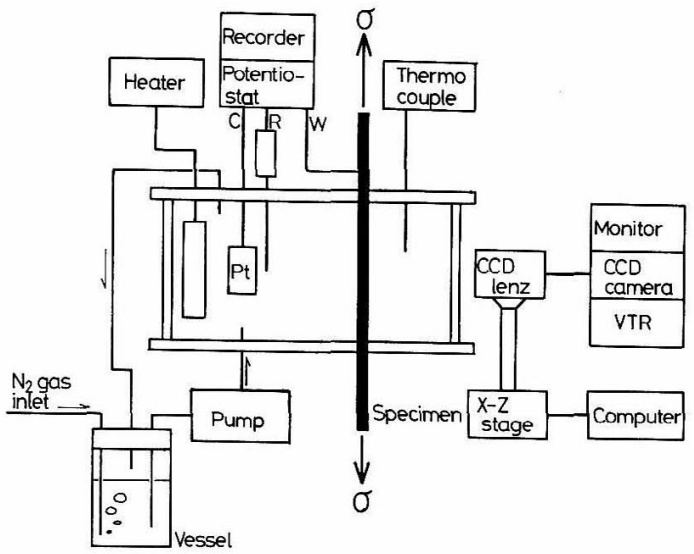

Fig. 2 Schematic diagram of the slow strain rate test with in-situ observation system by CCD camera.

装置の写真を示した。また，Fig. 2 には CCD カメラ付 SSRT 装置の構成図を, Fig. 3 亿は自作したセルの平面 図を示した。SSRT 装置は東伸工業(株)製 SSRT MINI1000 である。セルはCCD カィラによる試料表面の炎の 場観察に適した形状に，アリリル板を用いて自作した。 セルの形状は Fig. 3 に示したように注ぼ半円简形（高さ $80 \mathrm{~mm}$ ) であり, その平面側を $\mathrm{CCD}$ カメラの対物レン ズと対向させた。この観察方向のアクリル板 $\left(3 \mathrm{~mm}^{\mathrm{t}}\right)$ 外 面と試料表面との間隔は $18 \mathrm{~mm}$ である。

表面き裂の連続観察に用いた CCD カィラシステムは (株）モリテックス製 SCOPEMAN 503 である。この $\mathrm{CCD}$ カメラシステムの特徴は, $100 \mathrm{~W}$ ハロゲンランプ 光源からの高強度光を光つァイバーによって刘物レンズ の周用から被写体に均等に供給することにより, 非常に 被写界深度の深い映像を得ることができる点にある。本 研究に用いた，14インデニタ上での画面倍率が50倍と

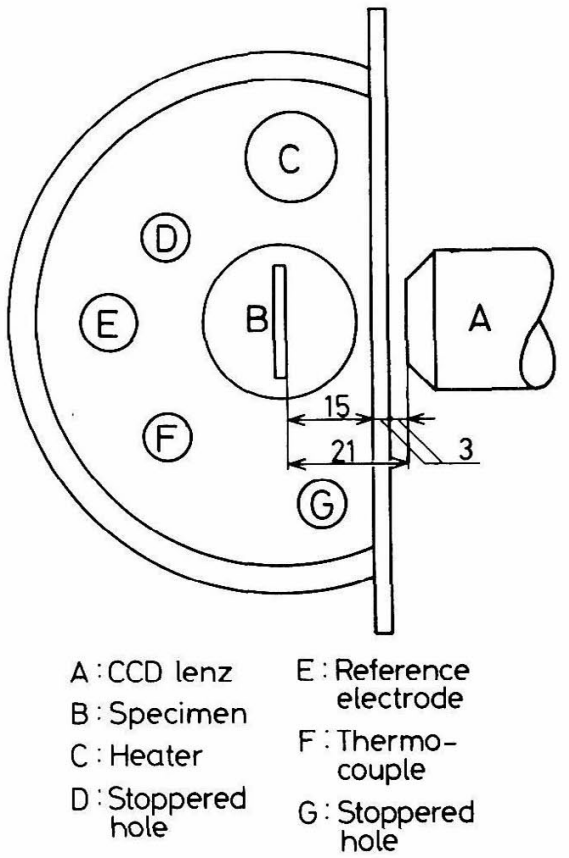

Fig. 3 Plane diagram of the cell of the slow strain rate test.

なる対物レンズの大気中での特性は, 作動距離 $14 \mathrm{~mm}$, 被写界深度 $4 \mathrm{~mm}$ となっているが，上述した $18 \mathrm{~mm} の$ (水溶液層十アクリル層)を通して観察した場合には作動 距離は約 $21 \mathrm{~mm}$ に迲する。したがって, 従来の光学 顕微鏡での SCC 挙動のその場観察に的ける久点であっ た短作動距離が大愊に改善され，試料表面とセル壁面と の距離を比較的離すことが可能となり, 試料近傍の水溶 液の温度分布を比較的均一にすることがでさた。

50 倍のレンズを装着した CCD カメラの測定視野は 約 $5 \times 4 \mathrm{~mm}$ である。そこで，X-Z ステージを用いて $\mathrm{CCD}$ カメラの対物レンズ部を二次元走査させ，この測 定視野より広い面積を持つ試料ダージ部全体に発生する 多数個のき裂をすべて観察することを可能とした。また， その観察結果は家廷用 VTR によって記録される。X-Z スラージの位置制御ならびに動作時間の制御はパーソナ ルコンピューター (NEC 製 PC-8801 mkII) とよって行 われているため，X-ZステージとVTR の動作時間を同 期させることで，尽夜を問わず定期的に，自動的に試料 ゲージ部全体に発生したき裂挙動の観察・記録を行らこ とができ，き裂の詳細な経時変化を得ることが可能とな った。

セルには,さらに参照電極, 対極も装備されており, ポテンシオスタットにより，SSRT 中に抢ける試料の自 然電位の測定ならびそ試料電位の制御を行うことができ る。ふたこれらの值はクロスへッド変位・荷重と同時 
にペンレコーダーに記録され，き裂の経時変化に対応さ せることができる。

\section{3. き裂の解析方法}

き裂観察システムにより観察・記録されたさ裂の発生 進展過程をVTR によって 14 インチモニター上に再現 し，個々のき裂長さを試験時間に対して測定した。この システムの分解能は約 $20 \mu \mathrm{m}$ である。この測定結果よ り,き裂の発生数および破壊力学的因子(つまり, $K_{\mathrm{ISCC}}$ およびき裂進展速度）などを解析し，き裂の発生と成長 を分離して評価することが可能となった。ところで, Newman, Jr.-Raju ${ }^{10)}$ は, 平板弾性体上に存在する Fig, 4 に示すような半棈円形の表面さ裂先端の任意の点 $\mathbf{P}$ に 対する応力拡大係数 $\left(K_{\mathrm{I}}\right)$ を三次元有限要素法により解 析し, 次の計算式を提案した。その計算式を次に示す。

$$
\begin{aligned}
K_{1}= & \sigma \sqrt{\pi a / Q} \cdot F(t, c, b, \phi) \\
Q= & 1+1.464(a / c)^{1.65} \\
F= & {\left[M_{1}+M_{2}(a / t)^{2}+M_{3}(a / t)^{4}\right] \cdot f_{\phi} \cdot g \cdot f_{w} } \\
M_{1}= & 1.13-0.09(a / c) \\
M_{2}= & -0.54+0.89 /[0.2+(a / c)] \\
M_{3}= & 0.5-1.0 /[0.65+(a / c)] \\
& \quad+14 \cdot[1.0-(a / c)]^{24} \\
g= & 1+\left[0.1+0.35(a / t)^{2}\right](1-\sin \phi)^{2} \\
f_{\phi}= & {\left[c^{2} \cos ^{2} \phi+\sin ^{2} \phi\right]^{0.25} } \\
f_{w}= & \{\sec [(\pi(a / c) / 2(c / b)) \cdot \sqrt{(a / t)}]\}^{0.5}
\end{aligned}
$$

ここで, $a$ はき裂深さ, $2 b$ は試料の幅, $2 c$ はき裂長さ, $t$ は試料の厚さ, $\phi$ は Fig. 4 中に示した角度である。本 研究に打ける $K_{\mathrm{I}}$ は, 塑性変形域でのき裂に対しても, この計算式に基づいて求められた。この場合, 表面き裂 の深さ方向の形状が非常に重要なのであるが, 本研究で は表面き裂の形状についてはまだ詳細に検討していない ので, 半円形と仮定した。また，表面のき裂長さを検討 の対象とするので, 表面(つまり $\phi=0)$ に和壮るき裂の $K_{\mathrm{I}}$ を算出した。

\section{4. 本試験装置による実験結果}

\section{1 実 験方法}

供試材である厚さ $2 \mathrm{~mm}$ のType $304 \mathrm{~L}$ 鋼板 $(\mathrm{C}: 0.028$, Si: $0.80, \mathrm{Mn}: 1.14, \mathrm{P}: 0.03, \mathrm{~S}: 0.01, \mathrm{Ni}: 10.18, \mathrm{Cr}$ :

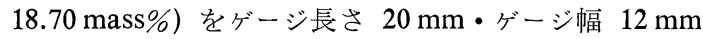
の平滑引張試験片に加工し, 溶体化処理 $(1323 \mathrm{~K} \times 3.6$ $\mathrm{ks}, \mathrm{WQ})$ を行った。この試験片をエメリー紙 $(\sim 6 / 0)$ で 研磨した後 SSRTに供した。

溶液には, 前報 ${ }^{11)}$ で SCC 感受性が高いことが示され た $20 \mathrm{mass} \% \mathrm{NaCl}+10^{-2} \mathrm{kmol} \cdot \mathrm{m}^{-3} \mathrm{Na}_{2} \mathrm{~S}_{2} \mathrm{O}_{3}$ 水溶液を $353 \mathrm{~K}$ にて用いた。また, この溶液は $\mathrm{HCl}$ により $\mathrm{pH} 4$ に調整されている。

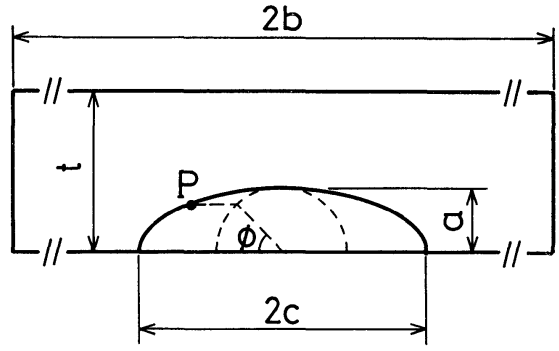

Fig. 4 Schematic diagram of a semi-elliptical surface crack in a finite-thickness plate.

次に実験手順を述べる。試料を取り付けたセル内に上 述の試験溶液を大気開放状態で導入し, 自然電位のほぼ 安定する $10.8 \mathrm{ks}$ 後に SSRTを開始した。SSRTに用い たひずみ速度は $8.3 \times 10^{-7} \mathrm{~s}^{-1}$ である。SSRT 開始と同時 に上述したき裂観察システムを動作させ, 試料観察面全 体のき裂の発生・進展過程を 2 3 時間ごとに観察・記 録した。また, 同時にクロスヘッド変位, 荷重および自 然電位も測定した。自然電位の測定には $\mathrm{Ag} / \mathrm{AgCl}(3.3$ $\mathrm{kmol} \cdot \mathrm{m}^{-3} \mathrm{KCl}$, 室温) 電極を参照電極として用い, 以下 に示す電位は測定值をそのます示した。

\section{2 実験結果および考察}

\subsection{1 試料の変形にともなう応力およびき裂長さの変} 化

SSRT の結果得られた。試料の変形にともなら応力お よび自然電位の变化を Fig. 5 に示した。応力はひずみの 増加にともない上昇し, 約 $40 \%$ のひずみ量に扣いて最 大值を示し, その後減少した。自然電位については, 試

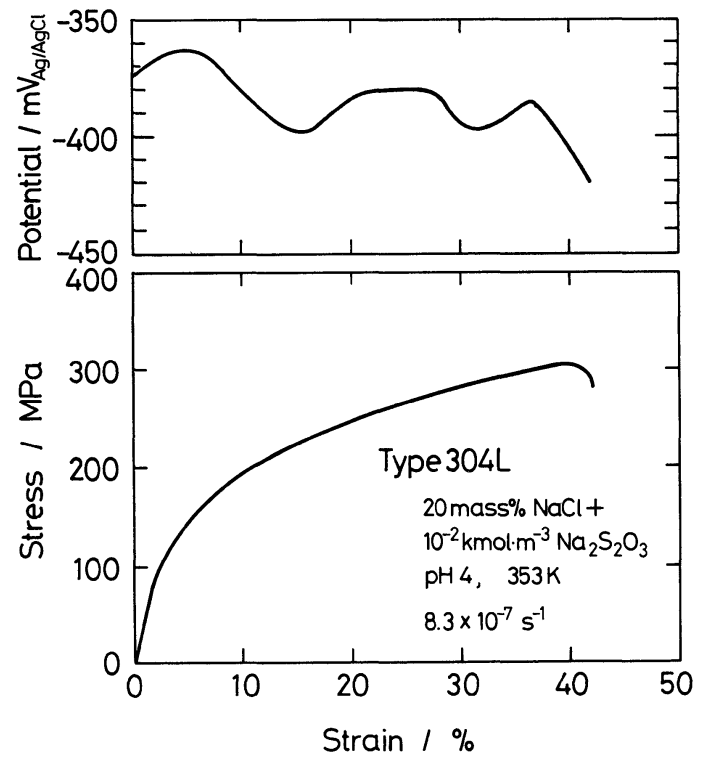

Fig. 5 Changes in stress and corrosion potential with strain at strain rate of $8.3 \times 10^{-7} \mathrm{~s}^{-1}$. 


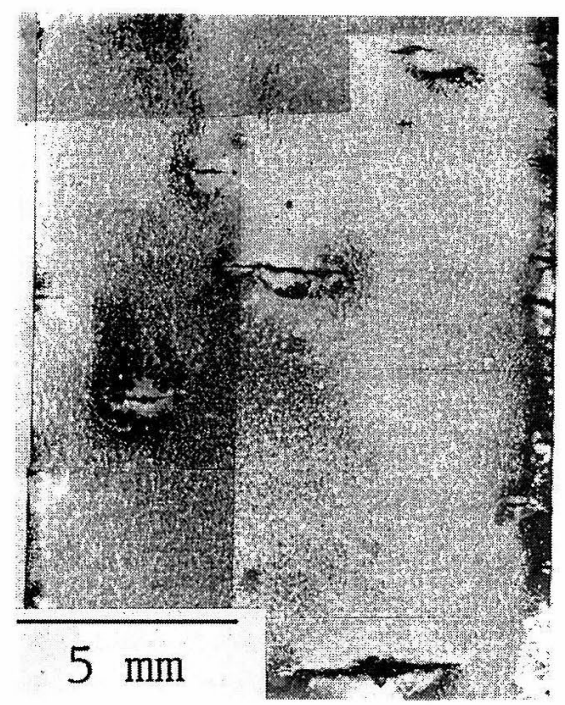

Fig. 6 Specimen surface after the slow strain rate test.
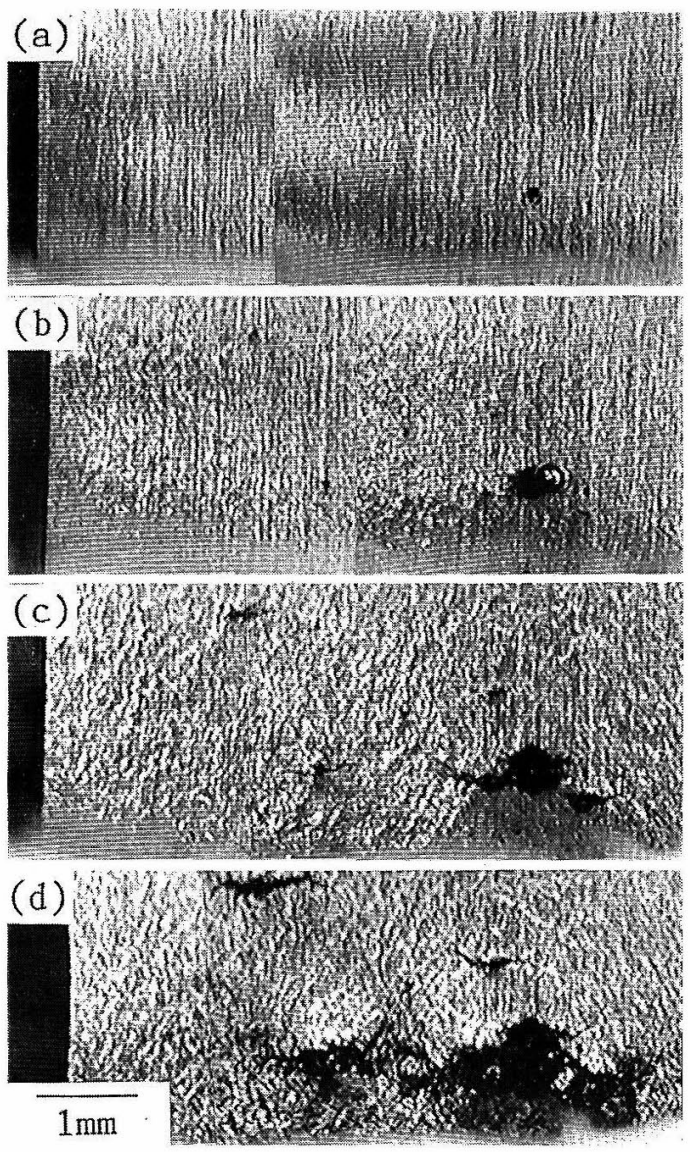

Fig. 7 Process of crack initiation and growth during the slow strain rate test by in-situ observation system; strain of (a) 11, (b) 25 , (c) 32 , (d) $39 \%$.

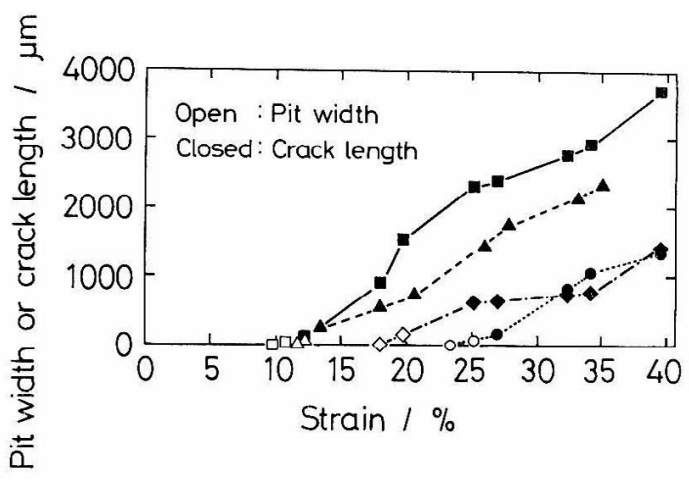

Fig. 8 Changes in length of each crack with strain.

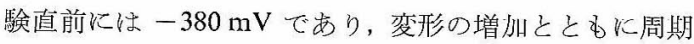
の長い振動を繰り返しながら徐々に降下した。

SSRT 後の試料表面を Fig. 6 に示した。この写真に 示したように, 試料表面には多数のき裂が発生・進展し, そのき裂のはぼ中央に孔食が認められだ1〉。またこの 写真から得られた全ゲージ部に発生したさ裂数ならびに

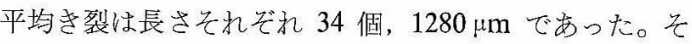
こで次に，上述したき裂観察システムを用いて，これら の多数個のき裂の発生・進展過程を個別に, 詳細に観察. 解析した。

\subsection{2 き裂観察システムによる表面き裂の観察結果}

き裂観察システムによって観察された, SSRT 中の試 料表面の経時变化を Fig. 7 に示した。この写真は, 同一 位置での観察結果である。この図にみられるよらに，ま ず，孔食が発生・成長し，あるひずみ量でき裂が孔食を 起点として発生し, 試料の変形にとむないき裂が成長す ることが明確に認められた。

SSRT 中に試料表面に発生・進展した個々のさ裂に対 して，その起点であった孔食の幅およびき裂長さのひず み量に対する変化をFig. 8 亿示した。図中の白印は孔食 径を，また黒印はき裂長さを示している。この図より， き裂はすべて孔食を起点に発生・進展すること, また, 一ののき裂に注目なると,さ裂はほぼ一定の進展速度で 成長することが認められた。さらに，各さ裂ごとに比較 すると孔食発生の潜伏侍間やき裂進展速度などに差が友 られた。そこで次に，き裂の起点である孔食の発生举動， ならびに個々のき裂の $K_{\mathrm{ISCC}}$ およびき裂進展速度を統計 的に評価・検討した。

\subsection{3 き裂の各因子に対する検討}

前述したように，本系でのき裂は孔食を起点として発 生する。したがって, 試験中に発生する孔食数の增加挙 動を評価することはき裂数を評洒することと同じ意味を 持つ。そこで, SSRT 中に括ける孔食数の増加挙動を調 


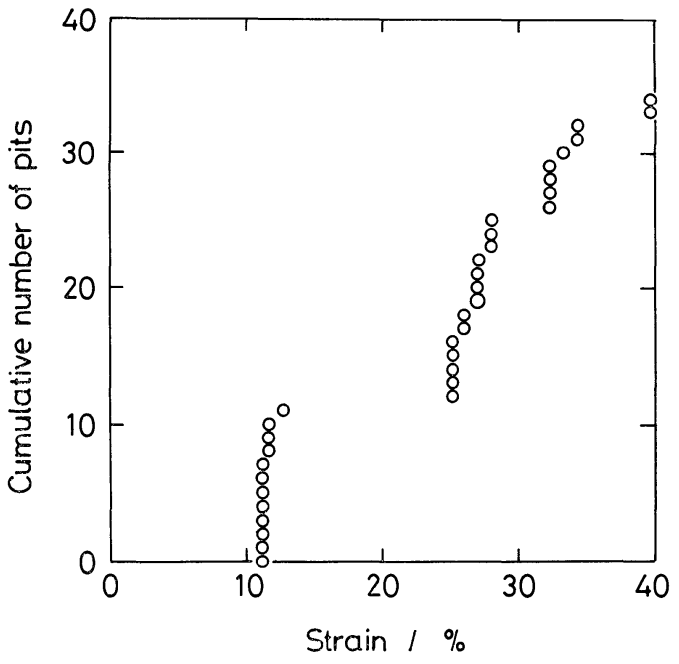

Fig. 9 Cumulative number of pits as a function of strain.

ベた。Fig. 9 には SSRT 中に乐けるひずみ量の増加に ともなら累積孔食数の変化を示した。この図により, 孔 食数はひずみの増加とともに増加することが明らかにな った。この結果は, 材料に塑性変形が生じ, 表面にすべ りステップが形成されることで, 不働態皮膜が破壊され, 孔食が容易に発生するというモデル12)で説明できる。

次に, 表面観察によって確認された, き裂発生直前の 孔食径から算出される応力拡大係数 $\left(K_{I_{\mathrm{pit}}}\right)$ およびき裂

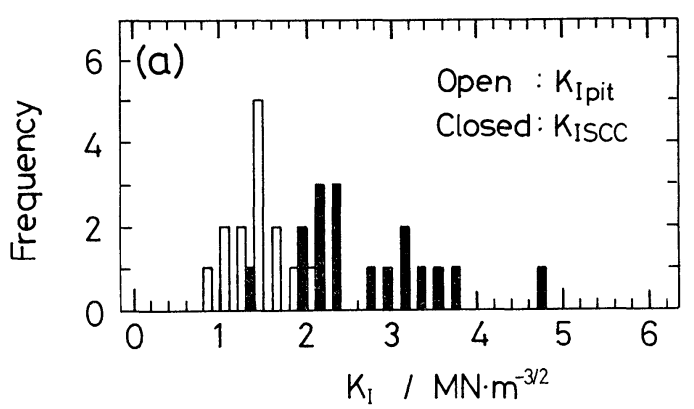

発生直後のき裂長さから算出される $K_{\mathrm{ISCC}}$ のヒストグラ ムを Fig. 10 (a) に示した。この戝にみられるように, それぞれの值がばらついていることがわかる。またこ れらの值の累積確率を平均ランク法 ${ }^{13)}$,14) により算出し ワイブル確率紙にプロットすると, Fig. 10 (b) に示した ように直線関係が成立し, ワイブル分布に従らことが確 認された。つまり, ワイブル分布が最弱リンクモデルか ら構築されている(5) ことを考慮すると, き裂はある力学 的条件に打いてもっともき裂を発生させや寸い孔食から 発生することが推察される。また, この図から得られる $K_{\mathrm{Ipit}}, K_{\mathrm{ISCC}}$ の最頻值（累積確率＝63\% のときの值）は それぞれ $1.6 \mathrm{MN} \cdot \mathrm{m}^{-3 / 2}, 2.7 \mathrm{MN} \cdot \mathrm{m}^{-3 / 2}$ であった。本研 究では 2 3 時間おきに試料表面を観察しているため, 孔食からき裂が発生する瞬間を観察することはできなか った。したがって, 真の $K_{\mathrm{ISCC}}$ の值は, 本解析での $K_{\mathrm{Ipit}}$ と $K_{\mathrm{ISCC}}$ との間の值, すなわち約 $2 \mathrm{MN} \cdot \mathrm{m}^{-3 / 2}$ であると 思われる。

一方, き裂進展速度のヒストグラムを Fig. 11 (a) に 示した。ただし, 各き裂長さはひずみ量（すなわち時間） に対して完全な直線関係を示さないため, 最小自乗法に よりさ裂進展速度を算出した。また, 図の横軸は対数で 示した。この図からわかるよらに, 約 $10^{-8} \mathrm{~m} \cdot \mathrm{s}^{-1}$ の進展 速度を持つき裂がもっとも多く, 低速度側により多くば らついた。このデータの累積確率を平均ランク 法 ${ }^{13), 14)}$ により算出し二重指数確率紙にプロットすると, Fig. 11

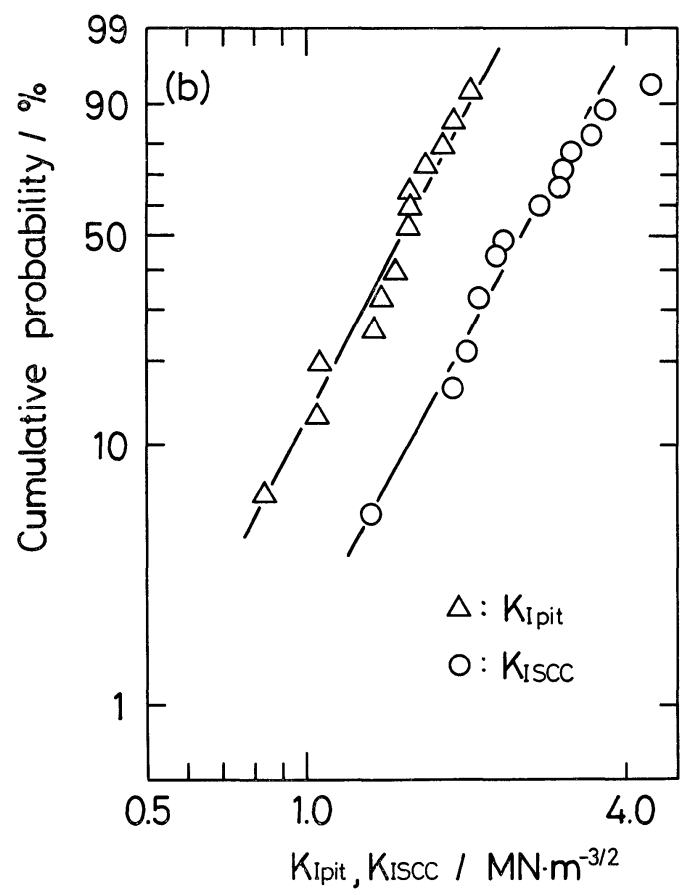

Fig. 10 Distributions of $K_{\text {ISCC }}$ and $K_{\text {Ipit }}$ which obtained from width of pit immediately before a crack generates; (a) histogram and (b) Weibull probability plot. 


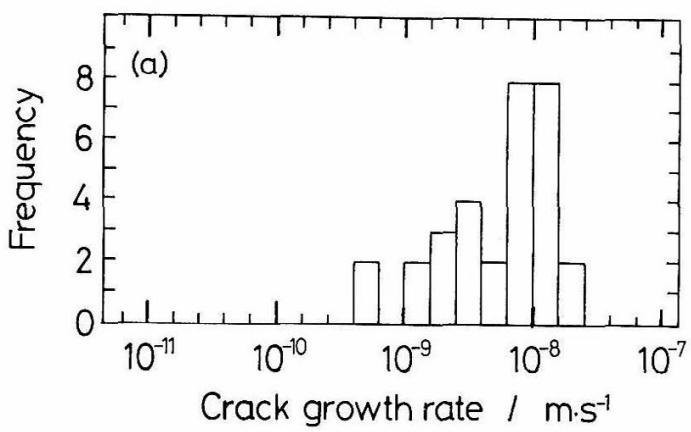

Fig. 11 Distribution of crack growth rate; (a) histogram and (b) double exponential probability plot.

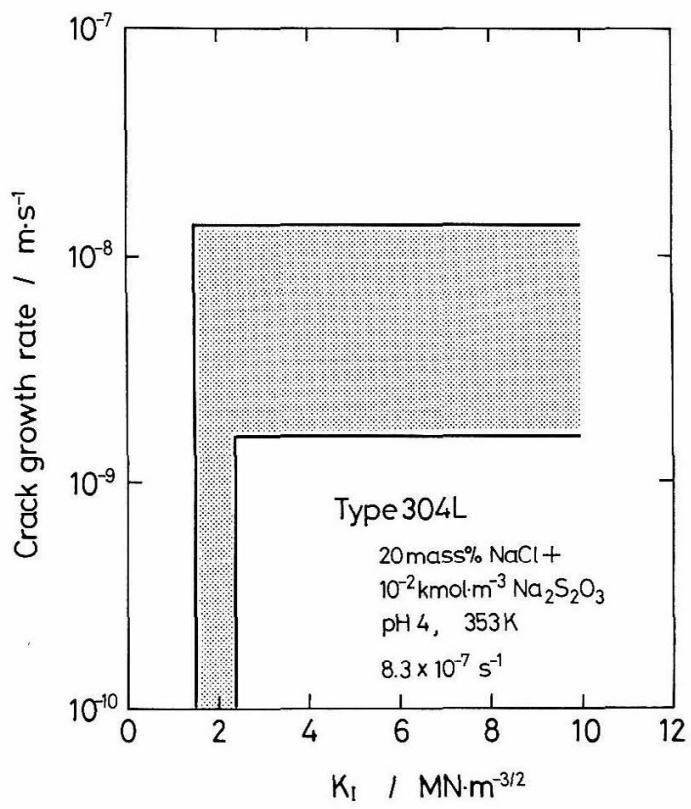

Fig. 12 Relation between crack growth rate and $K_{\text {I. }}$.

(b)により，確率が 10\% 90\% の範囲で直線関係が成 立し, き裂進展速度のばらつきは添淩二重指数分布に従 らことが明らかになった。

Fig. 12 には, 従来, 破壊力学の分野で用いられ, 上述 の結果から算出される $K_{\mathrm{I}}$ とき裂進展速度の関係を範囲 によって示した。以上の上うに, 孔食発生までの潜伏時 間， $K_{\mathrm{ISCC}}$ ならびにき裂進展速度にばらいきが生じるた めに，破断洔間などの従来用いられている SCC 評価因

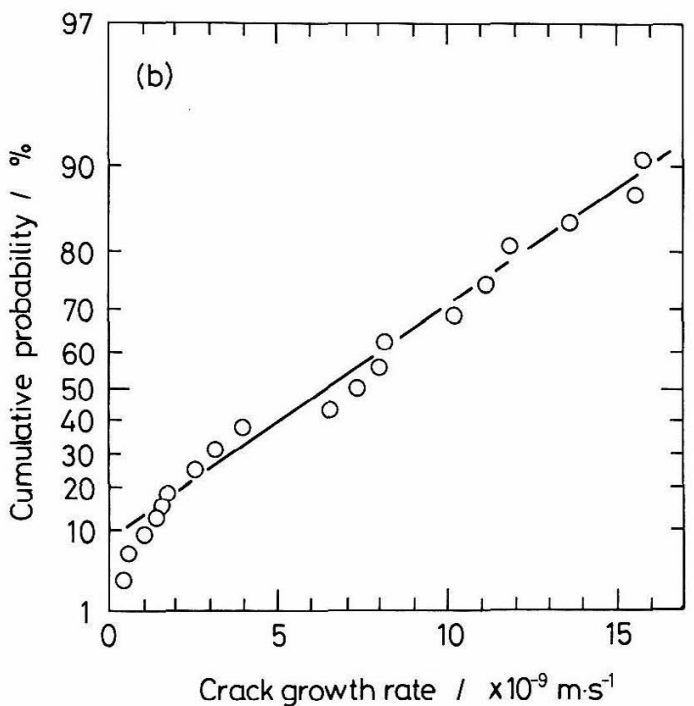

子にばらつきが生じることが明らかになった。

\section{5. 本 SCC 試験に対する今後の検討課題}

上述したように, SSRT 中の試料表面の直接観察によ り孔食の数・直径特よびき裂長さの成長過程から孔食数 のひずみ量依存性，個々のき裂の $K_{\mathrm{IscC}}$ ，き裂進展速度 を得ることができ，従来 SSRT に扣いて単純に評洒さ れた SCC 感受性をさらに詳細に検討できることを示す ことができた。今後の検討課題として次の点が挙げられ る。(1)より正確な $K_{\mathrm{ISCC}}$ を得るために，本解析の仮定で ある「き裂の形状が半円形であること」を詳細に検討す る必要がある。(2)き裂発生までの潜伏時間を経過するま でに応力が上昇するために $K_{1 \mathrm{ISC}}$ が多少過大評価される 恐れがあるため，ひずみ速度を変化させてひずみ速度に 依存しない $K_{\text {ISOC }}$ を求めることが必要である。(3)試料表 面に発生したき裂の挙動（ $K_{\text {ISCC }}$ ，き裂進展速度など）と 孔食底部で発生したき裂の挙動との対応関係を明確にす る必要がある。(4)本研究で用いた試料は破壊力学的解析 の条件である「完全弾性体」ではないため, 求めた $K_{\mathrm{ISCC}}$ は定性的な SCC 評価因子である。弾塑性体の破壊力学 的評価儿は $J$ 積分值を用いた方がより物理的飞意味があ るため, 現在, この評価法の本研究への導入を検討中で ある。これらの点を克服することによりさらに正確なき 裂の発生・進展挙動を低加工コストの平滑試験片を用い て，SSRTにより迅速に検討することができると思われ る。 


\section{6. 結言}

（1）SSRT 中に平滑試験片上に発生する多数個のき 裂の発生・進展過程を CCD カメラを用いて連続的に観 察するシステムを試作したことにより，試料表面上のき 裂挙動（数, 発生時間, $K_{\mathrm{ISCC}}$, き裂進展速度）を統計的 に解析することが可能となった。

(2) Type $304 \mathrm{~L} /\left(\mathrm{Na}_{2} \mathrm{~S}_{2} \mathrm{O}_{3}+\mathrm{NaCl}\right)$ 系での $\mathrm{SCC}$ に おいて, き裂の起点である孔食の数はひずみの増加とと もに増加した。

(3) $K_{\text {ISCC }}$ はワイブル分布を示し, その最頻值は約 $2 \mathrm{MN} \cdot \mathrm{m}^{-3 / 2}$ となった。また, き裂進展速度は二重指数 分布を示し, その最頻值は約 $10^{-8} \mathrm{~m} \cdot \mathrm{s}^{-1}$ となった。

(Received June 6, 1992)

\section{文献}

1) D. A. Vermilyea: Corrosion, 29, 442 (1973).

2) M. Hishida \& H. Nakada: Corrosion, 33, 332 (1977).

3) J. R. Cels: Corrosion, 34, 198 (1978).

4) J. K. Lee \& Z. Szklarska-Smialowska: Corro- sion, 44, 560 (1988).

5) D. R. Mclntyre, R. D. Kane \& S. M. Wilhelm: Corrosion, 44, 920 (1988).

6) 正村克身, 石沢嘉一, 稲積 透, 橋爪修司, 松島 巌：鉄と鋼, 74, 141 (1988).

7) 小若正倫, 長野博夫, 工藤䞢夫, 山中和夫：防食 技術，30，218 (1981).

8) 向井喜彦, 村田雅人: 溶接学会誌, 48, 937 (1979).

9）辻川茂男, 玉置克国，久松敬弘：鉄と鋼, 66, 2067 (1980).

10) J. C. Newman, Jr. \& I. S. Raju: Eng. Fract. Mech., 15, 185 (1981).

11）柴田俊夫, 春名 匠, 藤本慎司, 中根慎介：鉄と 鋼, 77, 1511 (1991).

12）高野道典，下平三郎：日本金属学会誌，29，553 (1965).

13) E. G. Gumbel: "Statistics of Extremes", Columbia University Press (1958).

14）腐食防食協会編：「装置材料の寿命予測入門」，p. 63, 丸善 (1984).

15) "A Statistical Theory of the Strength of Material", W. Weibull ed. : No. 151, Ingeniors Vetenskaps Akademieus Handligar, Stockholu (1939). 